\title{
PEMANFAATAN KANTIN KEJUJURAN SEBAGAI MODEL EVALUASI PENDIDIKAN KARAKTER SANTRI DI PONDOK PESANTREN ZUHRIYAH YOGYAKARTA
}

\author{
Husna Nashihin, Tri Asih \\ Sekolah Tinggi Agama Islam Nahdhatul Ulama Temanggung \\ e-mail: aufahusna.lecture2017@gmail.com
}

\begin{abstract}
Abstrak
Artikel ini merupakan penelitan lapangan yang menggunakan pendekatan Fenomenologi dalam menangkap ekspresi nilai karakter yang dilakukan santri melalui kantin kejujuran. Analisis data yang digunakan adalah analisis kualitatif. Penelitian ini memiliki latar belakang sebagai berikut; pertama, evaluasi pendidikan karakter yang berlangsung saat ini masih bersifat verbalistis. Kedua, belum adanya model evaluasi pendidikan karakter yang mampu mengarah pada evaluasi hasil belajar afektif. Ketiga, diperlukan pengembangan model evaluasi pendidikan karakter yang mampu mengarah pada ranah afektif. Keempat, Pondok Pesantren Zuhriyah merupakan lembaga pendidikan yang melakukan pemanfaatan kantin kejujuran sebagai model evaluasi pendidikan karakter. Kelima, belum adanya penelitian mengenai model evaluasi pendidikan karakter di Pondok Pesantren Zuhriyah. Selanjutnya ada dua hal yang urgen untuk dikaji, yaitu; pertama, konsep teoritis evaluasi pendidikan karakter di Pondok Pesantren Zuhriyah. Kedua, pemanfaatan kantin kejujuran sebagai model evaluasi pendidikan karakter di Pondok Pesantren Zuhriyah. Konsep teoritis evaluasi pendidikan karakter di Pondok Pesantren Zuhriyah sudah sesuai dengan konsp teoritis mengenai model, pendekatan, dan langkah-langkah evaluasi pendidikan karakter menurut beberapa tokoh pendidikan karakter. Berdasarkan pemanfaatan kantin kejujuran dalam evaluasi pendidikan karakter diketahui bahwa ada selisih pembayaran uang dalam kantin kejujuran sebesar $1,41 \%$. Kemudian berdasarkan analisis
\end{abstract}


kecenderuangan (trend analysis) diketahui bahwa ada kecenderungan penurunan selisih uang pembayaran yang dilakukan oleh santri selama proses evaluasi.

Kata Kunci: Kantin Kejujuran; Evaluasi Karakter; Pondok Pesantren Zuhriyah.

This article is a field research that uses the phenomenology approach in capturing the expression of character values carried out by santri through the honesty canteen. Data analysis used is qualitative analysis. This study has the following background; First, the evaluation of character education that is currently taking place is still verbalistic. Second, there is no character education evaluation model that can lead to the evaluation of affective learning outcomes. Third, it is necessary to develop a character education evaluation model that is able to lead to the affective domain. Fourth, Zuhriyah Islamic Boarding School is an educational institution that uses honesty canteen as a model for evaluating character education. Fifth, there is no research on the evaluation model of character education at Zuhriyah Islamic Boarding School. Furthermore, there are two urgent things to study, namely; first, the theoretical concept of evaluating character education at Zuhriyah Islamic Boarding School. Second, the use of honesty canteen as a model for evaluating character education at Zuhriyah Islamic Boarding School. The theoretical concept of evaluating character education at Zuhriyah Islamic Boarding School is in accordance with theoretical consumptions about the model, approach, and steps of evaluating character education according to several character education figures. Based on the utilization of honesty canteen in character education evaluation, it is known that there is a difference in the payment of money in the honesty canteen by $1.41 \%$. Then based on the tendency analysis, it is known that there is a tendency to decrease the difference in payment money made by santri during the evaluation process. 
Keywords: Honesty Canteen; Character Evaluation; Zuhriyah Islamic Boarding School.

\section{A. Pendahuluan}

Arus modernisasi dan globalisasi tidak bisa dipungkiri juga membawa dampak negatif yang sangat terasa, meskipun juga banyak memberikan dampak positif bagi masyarakat. Paling tidak arus ini telah menghantarkan orang tua sebagai pelaku pendidikan utama tergerus dalam kesibukan. Hal ini berimplikasi pada kurangnya perhatian orang tua terhadap perkembangan karakter anak yang sangat dipengaruhi oleh media informasi dan teknologi saat ini.Pelajar SD, SMP, dan SMA yang terlibat tawuran di DKI Jakarta mencapai 0,08\% atau sekitar 1.318 siswa dari total 1.647.835 sebagaimana yang disampaikan oleh Pusat Pengendalian Gangguan Sosial DKI Jakarta(Dharma Kesuma, dkk, 2011, p. 2).

Realitas menunjukan bahwa dekandensi moral, menjangkitnya ketidakadilan, mahalnya rasa solidaritas, dan lain sebagainya telah melanda masyarakat Indonesia dewasa ini (Doni Koesoema A, 2010, p. 4). Nilai karakter menjadi sangat urgen untuk diinternalisasikan kepada masyarakat Indonesia saat ini di tengah carut marutnya aspek moral yang semakin parah (Faisal Ismail, 1997, p. 23). Agaknya realitas ini cukup menjadi jawaban atas pertanyaan mendasar, ada apa dengan pendidikan di Indonesia saat ini sehingga belum bisa menghantarkan masyarakat yang dididik menjadi pribadi manusia yang lebih 
baik. Maka tidak heran jika pemerintah berupaya menjadikan karakter sebagai tujuan utama dalam kurikulum yang berlaku saat ini.

Dalam kamus psikologi dinyatakan bahwa karakter adalah kepribadian yang ditinjau dari titik tolak etis atau moral, misalnya kejujuran seseorang, biasanya memiliki keterkaitan dengan sifatsifat yang relatif tetap (Hamka Abdul Azis, 2011, pp. 197-198). Hal ini bersesuaian dengan makna karakter dalam kamus besar bahasa inggris yang menjelaskan bahwa character (karakter) adalah "The aggregate of features and traits form the individual nature of some persons or things" (The Random house Dictionary of English Language, 1983, p. 346) yang artinya keseluruhan ciri khas sifat dan perangai yang membentuk watak sekelompok orang atau barang. Hal ini sebagaimana ditegaskan oleh Ratna Megawati (2010, p. 5) yang menjelaskan bahwa pendidikan karakter adalah sebuah usaha untuk mendidik anak-anak agar dapat mengambil keputusan dengan bijak dan mempraktekannya dalam kehidupan sehari-hari, sehingga mereka dapat memberikan kontribusi yang positif kepada lingkungannya.

Terlepas dari pengembangan model pendidikan karakter yang senantiasa dilakukan, evaluasi pendidikan karakter yang berlangsung sampai saat ini belum menemukan formula yang tepat. Evaluasi yang dilakukan belum mengarah pada evaluasi hasil belajar afektif yang seharusnya menjadi fokus utama dalam evaluasi pendidikan karakter (Dharma Kesuma, dkk, 2011, p. 5). 
Pengembangan ranah afektif dalam evaluasi pendidikan karakter tersebut semakin urgen untuk direalisasikan mengingat bahwa secara umum evaluasi yang sudah banyak dilaksanakan saat ini belum menekankan pada model observasi perilaku, akan tetapi masih cenderung menggunakan skala sikap, sehingga nantinya pengembangan evaluasi ini juga mampu menjadi tawaran baru bagi dunia pendidikan.

Hal ini sejalan dengan pemaparan Dirjen Kelembagaan Agama Islam Departemen Agama tentang permasalahan evaluasi pendidikan Islam pada kutipan poin nomor 7 sebagai berikut; 7 . Ukuran keberhasilan pendidikan agama juga masih formalistas (verbalistis). ${ }^{1}$ Salah satu permasalahan pendidikan agama Islam adalah terletak pada evaluasi hasil belajar ranah afektif yang masih menggunakan ukuran keberhasilan secara formalitas, yaitu penilaian hasil belajar Pendidikan Agama Islam yang masih bersifat verbalistis. Untuk itu, diperlukan sebuah teknik evaluasi baru dengan strategi yang inovatif.

Pendidikan menjadi pondasi utama dalam pembentukan karakter bangsa. Namun demikian, tidak bisa dipungkiri pendidikan karakter yang sudah dikembangkan sampai saat ini masih sangat verbalistis. Hal ini juga dikuatkan oleh Dirjen Kelembagaan Agama Islam Departemen Agama yang memaparkan bahwa ukuran keberhasilan pendidikan agama juga

\footnotetext{
1 Abdul Majid dan Dian Andayani, Pendidikan Agama Islam Berbasis Kompetensi (Konsep dan Implementasi Kurikulum 2004, (Bandung: PT. Remaja Rosdakarya, 2005), hlm. IV.
} 
masih formalistas (verbalistis) (Abdul Majid dan Dian Andayani, 2005, p. IV).

Dalam Peraturan Pemerintah Nomor 192005 Pasal 64 Ayat 3 juga disebutkan bahwasanya penilaian hasil belajar kelompok mata pelajaran kewarganegaraan dan kepribadian dilakukan melalui pengamatan terhadap perubahan perilaku dan sikap untuk menilai perkembangan afektif dan kepribadian peserta didik serta ujian, ulangan, dan/atau penugasan untuk mengukur aspek kognitif peserta didik. ${ }^{2}$ Berdasarkan Peraturan Pemerintah di atas, Pendidikan Agama Islam sebagai kelompok mata pelajaran kepribadian memang seharusnya memiliki model evaluasi pengamatan yang mengedepanan ranah afektif.

Ada sebuah model evaluasi pendidikan karakter yang dikembangkan di Pondok Pesantren Zuhriyah Yogyakarta. Kantin kejujuran yang sudah berlangsung lama dikembangkan sebagai model evaluasi pendidikan karakter kejujuran. Meskipun terbatas pada karakter kejujuran saja, namun pemanfaatan ini menjadi menarik untuk dikaji karena banyak model pendidikan karakter dengan kantin kejujuran yang pengembangannya stagnan dan belum maksimal. Realisasi pengkajian ini semakin menjadi nyata ketika mempertimbangkan pendapat In'am Sulaiman yang menegaskan bahwa sampai saat ini pesantren telah terbukti mampu mempertahankan eksistensinya serta mampu menyesuai-

2 Zainal Arifin, Evaluasi Pembelajaran (Prinsip, Teknik, Prosedur), (Bandung: Remaja Rosdakarya, 2009), hlm. 47. 
kan dengan tuntutan zaman (In'am Sulaiman, 2010, p. ix).

Berdasarkan pemaparan diatas, maka ada beberapa alasan yang melatarbelakangi penelitian ini urgen untuk direalisasikan, yaitu; pertama, evaluasi pendidikan karakter yang berlangsung saat ini masih bersifat verbalistis. Kedua, belum adanya model evaluasi pendidikan karakter yang mampu mengarah pada evaluasi hasil belajar afektif. Ketiga, diperlukan pengembangan model evaluasi pendidikan karakter yang mampu mengarah pada ranah afektif. Keempat, Pondok Pesantren Zuhriyah merupakan lembaga pendidikan yang melakukan pemanfaatan kantin kejujuran sebagai model evaluasi pendidikan karakter. Kelima, belum adanya penelitian mengenai model evaluasi pendidikan karakter di Pondok Pesantren Zuhriyah.

Berdasarkan latar belakang tersebut, maka ada dua rumusan masalah yang perlu dikaji secara mendalam, yaitu pertama, konsep teoritis evaluasi pendidikan karakter di Pondok Pesantren Zuhriyah. Kedua, pemanfaatan kantin kejujuran sebagai model evaluasi pendidikan karakter di Pondok Pesantren Zuhriyah.

\section{B. Hasil dan Pembahasan}

1. Konsep Teoritis Evaluasi Pendidikan Karakter di Pondok Pesantren Zuhriyah

Pelaksanaan evaluasi pendidikan karakter yang dilakukan melalui pemanfaatan kantin kejujuran sesuai dengan konsepsi teoritis mengenai evaluasi pendidikan karakter 
sebagai berikut;

a. Pendekatan Pendidikan Karakter

Secara terminologis, "karakter" berasal dari bahasa yunani "charassein" yang berarti "mengukir" (Hamka Abdul Azis, 2011, p. 43). Terminologi ini munegaskan bahwa "ukiran" yang diposisikan sama dengan karakter memiliki sifat melekat kuat pada benda yang diukir.Abdullah Munir (2010, pp. 2-3)menambahkan bahwa karakter dideskripsikan sebagai sebuah pola yang terdiri dari pikiran, sikap, maupun tindakan yang sangat susah untuk dihilangkan dari diri seseorang. Pendidikan karakter harus dilaksanakan sejalan dengan pandangan pendidikan Islam, dimana inti dari hakikat nilai-nilai Islam adalah nilai yang membawa kemaslahatan dan kesejahteraan bagi seluruh makhluk (sesuai konsep rahmatan lil 'alamiin), demokratis, egalitarian, dan humanis (Haidar Putra Daulay, 2007, p. 16). Pengertian lainnya sebagaimana yang dikemukakan oleh Ratna Megawangi bahwa pendidikan karakter adalah sebuah usaha untuk mendidik anak-anak agar memiliki kecerdasan mengambil keputusan dengan bijak dan mempraktikanya dalam kehidupan sehari-hari, sehingga mereka dapat memberikan kontribusi yang positif kepada lingkungannya (Ratna Megawangi, 2010, p. 95).

Doni Koesoema (2010, pp. 90-91)memaparkan bahwa 
karakter dapat dipandang sebagai sebuah kondisi yang sudah ada dan harus diinternalisasikan dalam diri manusia. Kondisi seperti ini disebut sebagai given. Selain itu, karakter juga bisa dipandang sebagai sesuatu yang sengaja didesain dan diinternalisasikan dalam diri manusia. Kondisi yang demikian ini disebut sebagai willed.

Ada banyak pendapat tokoh pendidikan karakter berkenaan dengan pendekatan pendidikan karakter. Kirschenbaum misalnya memaparkan pendekatan komprehensif dalam pendidikan karakter. Kirschenbaum menyatakan pendekatan komprehensif dalam pendidikan nilai meliputi empat cara, yaitu inculcating value (inkulkasi), modelingvalue and (keteladanan), facilitating value and morality (fasilitasi nilai), skills for value development and moral literacy (pengembangan ketrampilan hidup) (Howard Kirschenbaum, 2000, pp. 31-43).

Nurul Zuriah menjelaskan bahwa pendekatan pendidikan nilai menjadi sangat penting guna mecapai tujuan pendidikan nasional yang sudah ditetapkan. Untuk itu, paling tidak ada dua pendekatan utama dalam pendidikan nilai, yaitu pendekatan penyisipan (plug in) dan pendekatan perbaikan (improvement) yang dilaksanakan dengan memaksimalkan isi, proses, dan pengelolaan pendidikan (Nurul Zuriah, 2011, p. 74).

Kedua pendekatan utama diatas, kemudian oleh Nurul 
Zuriah juga dijelaskan secara lebih rinci sebagai berikut: (2011, pp. 75-76)

b. Pendekatan Penanaman Nilai (Inculcation Approach)

Pendekatan penanaman nilai berusaha menjadikan peserta didik mengetahui dan menerima nilai karakter sebagai miliki sendiri serta bersedia bertanggung jawab atas segala keputusan dalam hidup yang telah diambil. Pendekatan ini dilaksanakan dengan melalui tahapan; mengenal berbagai pilihan karakter, menilai pilihan karakter yang diinginkan, menentukan pilihan karakter, dan menerapkan nilai karakter sesuai dengan kesadaran dirinya sendiri. Pendekatan ini dalam pelaksanaannya mengguna berbagai cara atau metode, antara lain; keteladanan, penguatan positif dan negatif, simulasi, serta bermain peran.

c. Pendekatan Perkembangan Moral Kognitif (Cognitive Moral Development Approach)

Pendekatan ini menekankan pada perkembangan pengetahuan moral peserta didik sesuai dengan tingkatannya. Selanjutnya, dalam implementasinya seorang pendidik kemudian mendorong peserta didiknya untuk membuat keputusan atas perbuatan yang akan dilaksanakan sesuai dengan moralnya. Pendekatan ini menuntut pemahaman antara kesesuaian perilaku dengan prinsipprinsip etika dan moral yang berlaku universal. Adapun dalam pelaksanaannya, pendekatan ini dapat menggunakan 
berbagai cara atau metode, antara lain; melaksanakan diskusi kelompok dengan tema besar mengenai moral, baik tema moral yang faktual maupun yang sebatas bersifat teoritis atau abstrak (hipotetikal).

d. Pendekatan Analisis Nilai (Value Analyzis Approach)

Pendekatan ini mengedepankan kemampuan berpikir analisis dan rasional peserta didik. Artinya, pendekatan ini berusaha memberikan peluang kepada peserta didik untuk menganalisis suatu masalah moral tertentu serta membuat sintesa antara masalah yang dihadapi dengan nilai karakter tertentu.Selanjutnyaa, dalam implementasinya, pendekatan ini dapat dilaksanakan dengan cara atau metode seperti; diskusi terarah yang menuntut argumentasi, penegasan dasar aargumentasi, penegasan prinsip, analisis terhadap kasus, debat, dan bahkan berupa penelitian.

e. Pendekatan Klarifikasi Nilai (Value Clarification Approach)

Pendekatan ini berusaha menumbuhkan kemampuan peserta didik dalam mengidentifikasi nilai karakter yang terkandung dalam sebuah aktifitas. Selanjutnya, berdasarkan hasil identifikasi karakter tersebut, peserta didik secara jujur diberikan ruang untuk mengkomunikasikan secara jujur kepada orang lain. Masukan yang diberikan tersebut berfungsi sebagai klarifikasi atas karakter yang telah diidentifikasi. Dalam implementasinya, pendekatan ini dapat menggunakan cara 
atau metode seperti; bermain peran, simulasi, analisis mendalam tentang nilai, aktivitas yang mengembangkan sensitivitas, kegiatan di luar kelas, dan diskusi kelompok.

f. Pendekatan Pembelajaran Berbuat (Action Learning Approach)

Sebenarnya konsep pendekatan ini kurang lebihnya sama dengan konsep pendekatan analisis nilai dan klarifikasi nilai. Pendekatan ini memberikan kesempatan kepada peserta didik untuk merealisasikan nilai karakter ke dalam sebuah perbuatan. Pendekatan ini mendorong peserta didik untuk berinteraksi dengan lingkungan sekitarnya sebagai makhluk sosial. Dalam implementasinya, pendekatan ini dapat dilaksanakan dengan cara atau metode antara lain;kegiatan sekolah berbasis proyek, kegiatan pengabdian masyarakat, serta kegiatan berbasis organisasi.

Berbagai pendekatan pendidikan karakter diatas merupakan pendekatan pendidikan karakter yang juga dilaksanakan di Pondok Pesantren Zuhriyah. Jika mencoba menilik dengan teori pendekatan karakter lain seperti Hersh, ternyata pendekatan di pesantren ini juga sudah sesuai secara teoritis.

Hampir senada dengan Nurul Zuriah, Hersh memaparkan ada enam pendekatan dalam pendidikan karakter yang biasa digunakan dalam praktek pendidikan karakter, yaitu; pendekatan pengembangan rasional, pendekatan pertimbangan nilai moral, pendekatan klarifikasi 
nilai, pendekatan pengembangan moral kognitif, pendekatan perilaku sosial, dan pendekatan penanaman nilai. Selanjutnya, Elias yang mencoba mensintesiskan berbagai teori mengenai pendekatan pendidikan karakter tersebut, menyimpulkan pendekatan pendidikan karakter menjadi tiga, yaitu; pendekatan kognitif, pendekatan afektif, dan pendekatan perilaku (Maksudin, 2009, pp. 26-28).

Secara lebih luas dan komprehensif, selanjutnya Kirschenbaum memaparkan pendekatan dalam pendidikan karakter menjadi empat, yaitu inculcating value (inkulkasi), modelingvalue and (keteladanan), facilitating value and morality (fasilitasi nilai), skills for value development and moral literacy (pengembangan ketrampilan hidup) (Howard Kirschenbaum, 2000, pp. 31-43). Pendekatan Kirschenbeum ini kemudian lebih dikenal dengan pendekatan komprehensif pendidikan karakter.

Secara substansial, definisi komprehensif yang dimaksud dalam pendekatan ini mencakup empat hal, yaitu isi, metode, hal yang terjadi dalam semua aspek kegiatandi sekolah, serta hal yang terjadi dalam kehidupan masyarakat (Darmiyati Zuchdi, 2010, pp. 113-114).

\section{Langkah-Langkah Evaluasi Pendidikan Karakter}

Evaluasi pendidikan nilai moral menurut Darmiyati Zuchdi dilakukan untuk mengetahui ketercapaian tujuan yang meliputi tiga kawasan yakni pemikiran, perasaan, dan perilaku 
(Darmiyati Zuchdi, 2010, p. 51). Untuk itu, evaluasi pendidikan nilai dapat dilanjutkan setelah melakukan evaluasi pada tingkat penalaran moral (moral knowing), evaluasi pada tingkat perasaan moralnya (moral feeling), dan terahir dilakukan evaluasi pada tingkat tindakan moralnya (moral action). Kementerian Pendidikan Nasional megungkapkan bahwa penilaian keberhasilan pendidikan karakter dilakukan dengan langkah langkah sebagai berikut: (Kemendiknas, 2011, p. 18)

a. Mengembangkan indikator dari nilai-nilai yang ditetapkan dan disepakati.

b. Menyusun berbagai instrumen penilaian.

c. Melakukan pencatatan terhadap pencapaian indikator.

d. Melakukan analisis dan evaluasi.

e. Melakukan tindak lanjut.

Indikator terkait nilai karakter yang akan disusun sebaiknya menggunakan pernyataan yang konkrit, sehingga indikator tersebut dapat diukur atau measurable. Instrumen penilaian yang akan digunakan untuk mengukur karakter seharusnya tidak hanya berupa teknik terulis seperti tes atau angket, akan tetapi perlu ditambahkan teknik observasi atau pengamatan sehingga penilaian karakter lebih obyektif. Selain langkah-langkah evaluasi, perlu juga diketahui aspek-aspek yang harus diperimbangkan dalam evaluasi. Paul Suparno mengungkapkan beberapa aspek tentang evaluasi budi pekerti, yaitu kelakuan, kerajinan, dan kerapian (Paul Suparno, 1997, p. 
90). Pendapat Paul Suparno tersebut meskipun dimaksudkan untuk evaluasi budi pekerti pada pendidikan formal, akan tetapi juga relevan diterapkan di pendidikan pondok pesantren dengan mengevaluasi akhlak keseharian, kerajinan mengaji kitab, dan kerapian kamar santri.

Ada dua model penilaian, yaitu model penilaian kuantitatif dan penilaian kualitatif. Penilaian kuantitatif yaitu penyajian hasil penilaian dengan menggunakan angka dan berpegang pada rentetan angka 1 sampai dengan 10. Penilaian kualitatif yaitu penilaian dengan menggunakan pernyataan verbal, misalnya baik sekali, baik, sedang, kurang, atau kurang sekali. Rumusan penilaian akan mengungkapkan hal hal yang positif dari sebuah aspek perilaku, kemudian menunjukan kekurangan dan upaya perbaikan yang mesti dilakukan.

Guna memperoleh hasil penilaian pendidikan bidu pekerti perserta didik dalam kehidupan sehari hari, seorang guru perlu menyiapkan instrumen penilaian. Instrumen penilaian dapat berupa lembar observasi, lembar skala sikap, lembar porto folio, lembar check list, dan lembar pedoman wawancara (Kemendiknas, 2011, p. 27). Evaluasi dengan memanfaatkan kantin kejujuran yang dilakukan di Pondok Pesantren Zuhriyah ini merupakan pengembangan dari tehnik observasi yang berusaha mengobservasi sikap natural santri dalam mengekspresikan kejujuran yang dimiliki.

Agar tidak jatuh dalam sikap subjektif yang cenderung 
mengarah kepada penilaian suka atau tidak suka terhadap santri, penilai sebaiknya terdiri dari unsur kyai dan ustadz. Adapun variabel yang dinilai oleh penilai seharusnya juga perilaku yang bersifat konkret. Kejujuran dalam penelitian ini diwujudkan dengan indikator konkrit berupa sikap membayar barang sesuai dengan daftar harga yangtelah disediakan. Guna mengetahui ketercapaian indikator ini, maka pemanfaatan kantin kejujuran dilakukan yang selanjutnya dianalisis menggunanan analisis kecenderuangan (trend analysis).

\section{Pemanfaatan Kantin Kejujuran Sebagai Model Evaluasi} Pendidikan Karakter di Pondok Pesantren Zuhriyah

Pelaksanaan evaluasi tingkat kejujuran santri yang dilakukan melalui pemanfaatan kantin kejujuran dapat dijelaskan dalam proses dan hasil evaluasi sebagai berikut;

a. Model Evaluasi Pendidikan Karakter

Model pendidikan karakter di atas dilaksanakan dalam sebuah proses pembentukan karakter yang dapat dilakukan dengan menekankan beberapa komponen, seperti yang dikemukakan oleh Lickona mengenai pentingnya menekankan tiga komponen karakter yang baik (Components of Good Character), yaitu; moral knowing, moral feeling, moral action(Mansur Muslich, 2011, p. 133).

Model penanaman karakter seperti ini ternyata sesuai dengan konsep yang dijelaskan Novan dalam bukunya mengenai manajemen karakter. Proses tersebut 
digambarkan sebagai berikut:(Novan Ardy Wiyani, 2010, p. 44)

Dalam konteks pendidikan nasional, pendidikan karakter memiliki beberapa fungsi strategis, yaitu; pengembangan potensi dasar agar berhati baik, berpikiran baik, dan berperilaku baik, perbaikan perilaku yang kurang baik dan penguatan perilaku yang sudah baik, dan penyaring budaya yang kurang sesuai dengan nilai-nilai luhur Pancasila (Dharma Kesuma, dkk, 2011, p. 46).

Model evaluasi yang akan diterapkan di Pondok Pesantren Zuhriyah merupakan pengembangan dari teknik observasi. Observasi dilakukan dengan cara memberikan ruang kesempatan kepada santri untuk mengekspresikan karakter yang dimiliki secara natural dengan berbasis pada kesadaran. Model evaluasi pada penelitian kali ini diberi nama "kantin kejujuran". Pelaksanaan model evaluasi ini menjadi hal yang sangat rahasia bagi santri. Peneliti berkerja sama dengan pemimpin pesantren untuk bisa menjaga kerahasiaan evaluasi pendidikan karakter yang akan dilaksanakan. Model evaluasi “kantin kejujuran” ini sengaja memberikan kebebasan kepada siswa untuk mengekspresikan karakter yang dimiliki dengan membayar atau tidak membayar jajanan yang diambil sesuai dengan daftar harga yang sudah ditentukan. Melalui model evaluasi ini, maka karakter-karakter santri yang dapat dievaluasi 
adalah sebagai berikut:

1) Keimanan dan Ketakwaan

Keimanan dan ketakwaan santri dapat diukur melalui model evaluasi "kantin kejujuran". Salah satu sikap sebagai wujud kristalisasi keimanan dan ketaqwaan seseorang adalah dengan tidak memakan harta yang haram. Jajanan yang diambil dan tidak dibayar oleh santri merupakan makanan haram yang tidak mungkin dilakukan oleh seseorang yang memiliki keimanan dan ketakwaan yang tinggi. Untuk itu, dengan "kantin kejujuran", peneliti akan mengetahui tingkat keimanan dan ketakwaan santri di Pondok Pesantren Zuhriyah.

2) Kejujuran

Tingkat kejujuran santri dapat diukur dengan menggunakan model "kantin kejujuran" karena santri yang jujur tidak akan mengambil jajanan tanpa membayar, meskipun tidak ada penjaga makanan di kantin tersebut. Santri yang jujur pasti akan membayar jajanan yang telah diambil sesuai dengan daftar harga yang ada.

3) Tanggung Jawab

Tingkat tanggung jawab santri dalam evaluasi ini dapat diukur dengan melihat sikap tangung jawab santri dalam membayarkan jajanan sesuai dengan daftar harga yang telah disediakan. Santri yang memiliki tanggung jawab 
tidak akan meninggalkan tanggung jawabnya setelah mengambil jajanan di "kantin kejujuran" dengan membayar sesuai yang terdapat di dalam daftar harga.

4) Kedisiplinan

Sikap kedisiplinan santri dapat ditunjukan dengan membayar uang jajanan secara disiplin sesuai dengan daftar harga yang telah ditentukan. Santri yang memiliki sikap disiplin tinggi akan membayar jajanan yang telah diambil sesuai dengan daftar harga yang ada.

Nilai-nilai karakter yang dapat dievaluasi dengan menggunakan model evaluasi "kantin kejujuran" ini memang terbatas pada empat karakter saja. Hal ini disebabkab karena keterbatasan model evaluasi yang didesain. Meskipun demikian, pada dasarnya model evaluasi ini lebih mampu mengukur karakter yang dimiliki santri secara lebih natural. Hal ini tentunya akan menjadikan hasil evaluasi lebih obyektif jika dibandingkan dengan model evaluasi dengan menggunakan teknik lain selain teknik observasi.

Model evaluasi "kantin kejujuran” ini pada dasarnya terinspirasi dari evaluasi yang pernah diselenggarakan di beberapa Negara di Eropa dan Amerika yang diberi nama “The Wallet Test". Evaluasi "The Wallet Test" dilakukan dengan mendesain kejadian dompet hilang. Dompet yang sengaja dihilangkan berisikan sejumlah uang dan kartu 
nama, sehingga hal itu memungkinkan kepada orang yang menemukan untuk bisa mengembalikannya kepada yang berhak. Melalui teknik ini, seseorang akan bisa mengekspresikan karakter yang dimiliki secara natural, seperti karakter kejujuran dan tanggung jawab.

Berikut ini desain model evaluasi yang akan diselenggarakan di Pondok Pesantren Zuhriyah:

a. Metode Evaluasi Pendidikan Karakter

Metode evaluasi yang akan digunakan dalam evaluasi pendidikan karakter di Pondok Pesantren Zuhriyah merupakan pengembangan dari teknik observasi. Observasi dilakukan dengan cara tersembunyi. Peneliti mengobservasi karakter siswa dengan menggunakan instrumen evaluasi yang digunakan. Evaluasi dilaksanakan dalam beberapa kali siklus evaluasi. Selama siklus evaluasi dilaksanakan, peneliti bekerja sama dengan Umi Yaya dan semua ustadz yang ada untuk memberikan penekanan terhadap pentingnya karakter yang akan diukur, yaitu keimanan dan ketakwaan, kejujuran, tanggung jawab dan kedisiplinan. Selanjutnya, peneliti akan melakukan analisis terhadap setiap siklus evaluasi yang telah dilaksanakan dengan menggunakan teknik analisis tren atau trend analyzis dengan melihat kecenderungan yang muncul di setiap siklus.

b. Instrumen Evaluasi Pendidikan Karakter 
Instrumen evaluasi pendidikan karakter yang digunakan berupa kantin yang didalamnya berisikan aneka jajanan dengan harga yang sudah ditentukan. Sesuai dengan namanya "kantin kejujuran", maka operasional kantin ini juga dilakukan berdasar pada kejujuran santri. Menu jajanan yang terdapat di kantin ini sudah dilengkapi dengan daftar harga, sehingga dalam pelaksanaannya santri bisa mengambil jajanan yang diinginkan dan santri diminta membayar secara mandiri dengan memasukan uang pembayaran ke dalam tempat yang telah disiapkan.

c. Siklus Evaluasi Pendidikan Karakter

Siklus evaluasi pendidikan karakter ini dilaksanakan sebanyak 10 kali. Selanjutnya, peneliti melakukan pengecekan atau observasi pada setiap siklus evaluasi. Observasi dilakukan dengan melakukan analisis membandingkan antara jumlah uang yang seharusnya didapatkan dengan jumlah uang yang senyatanya didapatkan.

d. Proses Evaluasi Pendidikan Karakter

Sebelum melaksanakan evaluasi peneliti terlebih dahulu mempersiapkan kantin sebagai intrumen evaluasi yang akan digunakan. Kantin yang akan digunakan berupa meja dan rak yang berisikan menu jajanan bagi santri. Peneliti juga menyediakan daftar harga jajanan yang akan diperjual-belikan. Selama proses evaluasi, kantin ini 
sebagaimana namanya "kantin kejujuran", tidak dijaga oleh pemiliknya dalam hal ini peneliti. Hal ini dilakukan untuk memberikan ruang kesempatan kepada santri untuk mengekspresikan karakter yang dimilki secara natural, sehingga hasil yang didapatkan lebih obyektif. Siklus evaluasi pendidikan karakter dilaksanakan mulai tanggal 9 sampai 18 April 2019 bertempat di aula Pondok Pesantren Zuhriyah selama 24 jam dalam sehari.

\section{Hasil Evaluasi Pendidikan Karakter}

\begin{tabular}{|c|c|c|c|c|c|}
\hline No & Tanggal & $\begin{array}{c}\text { Jumlah } \\
\text { uang } \\
\text { seharusnya }\end{array}$ & $\begin{array}{c}\text { Jumlah } \\
\text { Uang } \\
\text { Senyatanya }\end{array}$ & $\begin{array}{c}\text { Selisih } \\
\text { Uang }\end{array}$ & $\begin{array}{c}\text { Prosentase } \\
\text { Selisih } \\
\text { Uang }\end{array}$ \\
\hline 1. & $5 / 04 / 2019$ & Rp.33.400 & Rp.31.100 & Rp.2.300 & $6.88 \%$ \\
\hline 2. & $6 / 04 / 2019$ & Rp.26.500 & Rp.26.000 & Rp.500 & $1.88 \%$ \\
\hline 3. & $7 / 04 / 2019$ & Rp.27.100 & Rp.26.500 & Rp.600 & $2.21 \%$ \\
\hline 4. & $8 / 04 / 2019$ & Rp.35.500 & Rp.35.500 & - & - \\
\hline 5. & $9 / 04 / 2019$ & Rp.15.600 & Rp.15.500 & Rp.100 & $0.64 \%$ \\
\hline 6. & $10 / 04 / 2019$ & Rp.20.000 & Rp.20.000 & - & - \\
\hline 7. & $11 / 04 / 2019$ & $R p .23 .200$ & Rp.23.000 & Rp.200 & $0.86 \%$ \\
\hline 8. & $12 / 04 / 2019$ & Rp.25.500 & Rp.25.500 & - & - \\
\hline 9. & $13 / 04 / 2019$ & Rp.25.000 & Rp.25.000 & - & - \\
\hline 10. & $14 / 04 / 2019$ & $R p .30 .000$ & Rp.30.000 & - & - \\
\hline & Total & Rp.261.800 & Rp.258.100 & Rp.3700 & $\mathbf{1 . 4 1 \%}$ \\
\hline
\end{tabular}

Berdasarkan tabel di atas, dapat diketahui bahwa prosentase jumlah selisih uang atau uang yang tidak terbayarkan oleh santri di dalam "kantin kejujuran" sebanyak $1,41 \%$ dari total pemasukan uang yang seharusnya terbayarkan oleh santri. Adapun jika dilihat dari hasil evaluasi perharinya, maka lima (5) dari sepuluh (10) hari evaluasi pendidikan 
karakter melalui "kantin kejujuran" yang tidak memiliki selisih uang pembayaran atau tidak terdapat uang yang tidak terbayarkan oleh santri. Artinya, perlu ada evaluasi lebih lanjut mengenai faktor penyebab adanya uang yang tidak terbayarkan dalam lima (5) hari evaluasi pendidikan karakter tersebut.

Selanjutnya, peneliti akan menganalisis prosentase selisih uang dari evaluasi yang pertama sampai evaluasi yang kesepuluh. Berdasarkan tabel di atas, maka berikut ini diagram prosentase selisih uang evaluasi pendidikan karakter melalui “kantin kejujuran" yang sudah dilakukan oleh peneliti:

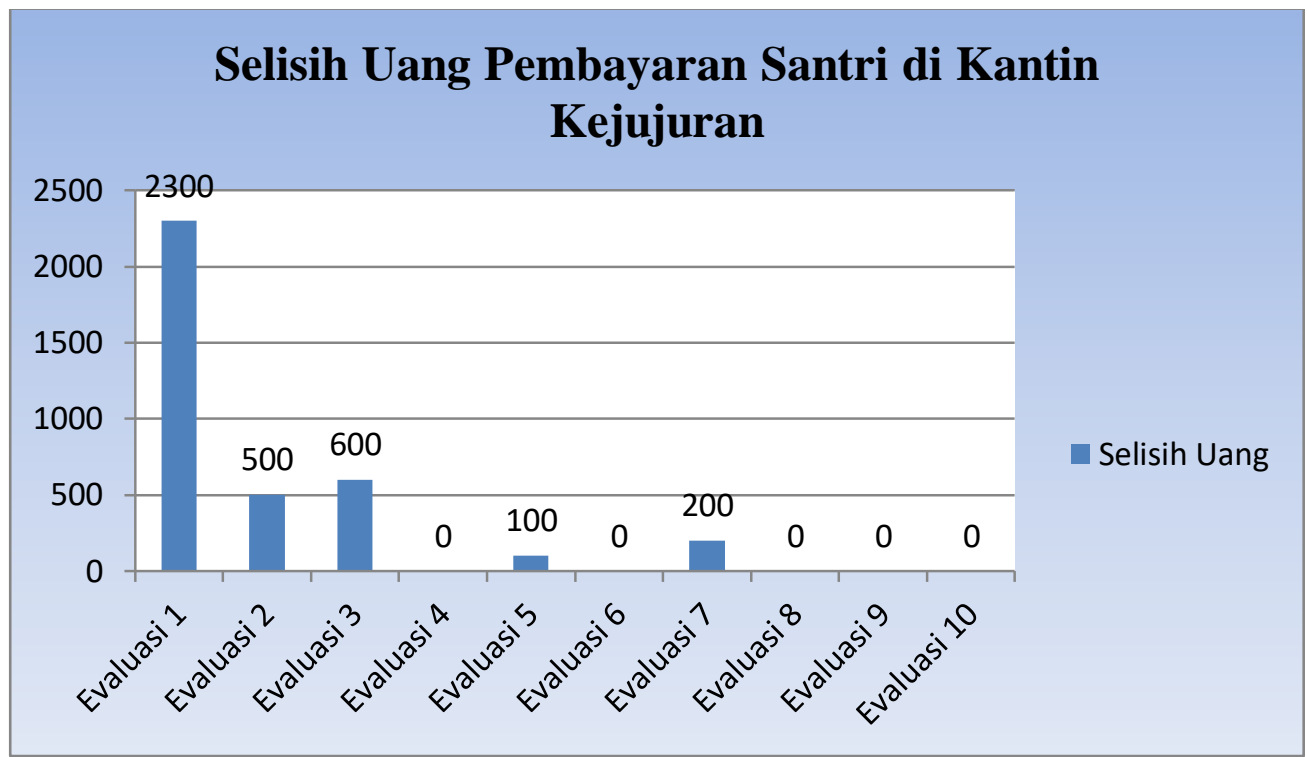

Berdasarkan data di atas, diketahui bahwa pada evaluasi pertama terdapat selisih uang pembayaran sebanyak Rp.2300. Nominal ini merupakan nominal selisih uang pembayaran yang paling besar selama proses evaluasi berlangsung jika 
dibandingkan dengan evaluasi lainnya yaitu Rp.500 pada evaluasi yang kedua, Rp.600 pada evaluasi yang ketiga, Rp.100 pada evaluasi yang kelima, dan Rp.200 pada evaluasi yang ketujuh. Adapun pada evaluasi yang keempat, keenam, kedelapan, kesembilan, dan kesepuluh menunjukan tidak adanya selisih uang pembayaran dari santri ketika membeli jajanan di kantin kejujuran yang didesain untuk evaluasi pendidikan karakter.

Selanjutnya, guna mengetahui kecenderungan naik dan turunya selisi uang pembayaran santri di kantin kejujuran, maka berikut ini diagram garis mengenai selisih uang pembayaran santri di dalam kantin kejujuran:

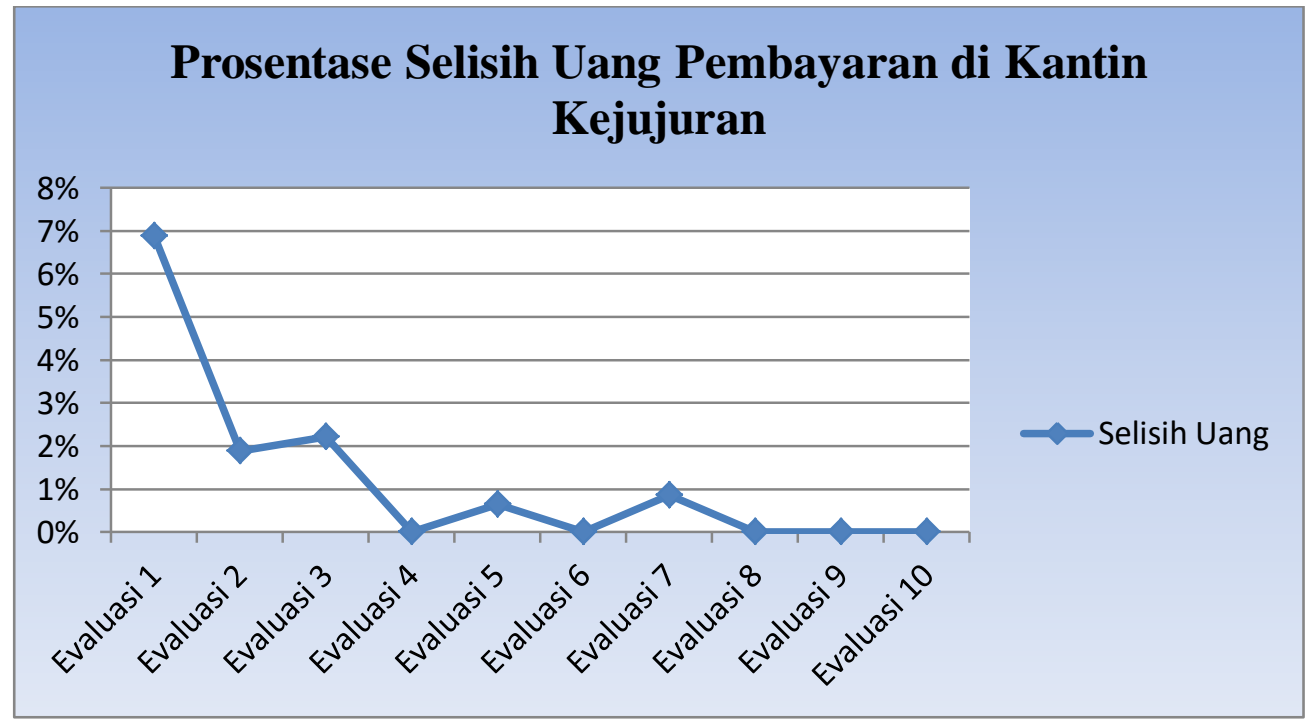

Berdasarkan grafik prosentase selisih uang pembayaran santri di kantin kejujuran di atas, maka dapat disimpulkan bahwa ada kecenderungan penurunan selisih uang pembayaran yang dilakukan oleh santri selama proses 
evaluasi, bahkan pada tiga evaluasi yang terahir menunjukan tidak adanya selisih uang pembayaran di dalam kantin kejujuran. Artinya, sikap atau karakter yang dapat diukur melalui model evaluasi pendidikan karakter berbentuk "kantin kejujuran" dapat tertanam dengan baik. Kelebihan hasil evaluasi ini lebih natural jika dibandingkan dengan evaluasi pendidikan karakter lainnya. Adapun karakter-karakter tersebut antara lain; keimanan dan ketakwaan, kejujuran, kedisiplinan, dan tanggung jawab.

\section{Kesimpulan}

Pelaksanaan evaluasi pendidikan karakter santri yang dilakukan dengan memanfaatkan kantin kejujuran merupakan usaha mendapatkan evaluasi nilai karakter yang natural. Evaluasi ini merupakan pengembangan tehnik observasi pendidikan karakter. Evaluasi ini dilakukan sebanyak sepuluh kali.

Berdasarkan evaluasi yang dilakukan diketahui bahwa ada selisih pembayaran uang dalam kantin kejujuran sebesar 1,41\%. Kemudian berdasarkan analisis kecenderuangan (trend analysis) yang dilakukan diketahui bahwa ada kecenderungan penurunan selisih uang pembayaran yang dilakukan oleh santri selama proses evaluasi, bahkan pada tiga evaluasi yang terahir menunjukan tidak adanya selisih uang pembayaran di dalam kantin kejujuran. Artinya, sikap atau karakter yang dapat diukur 
Husna Nashihin, Tri Asih

melalui model evaluasi pendidikan karakter berbentuk "kantin kejujuran" dapat tertanam dengan baik. 
Abdul Majid dan Dian Andayani. (2005). Pendidikan Agama Islam Berbasis Kompetensi (Konsep dan Implementasi Kurikulum 2004. Bandung: Remaja Rosda Karya.

Abdullah Munir. (2010). Pendidikan Karakter (Membangun Karakter Anak Sejak Dari Rumah). Yogyakarta: Pedagogia.

Darmiyati Zuchdi. (2010). Humanisasi Pendidikan (edisi ketiga). Jakarta: Bumi Aksara.

Dharma Kesuma, dkk. (2011). Pendidikan Karakter Kajian Teori dan Praktik di Sekolah. Bandung: Remaja Rosda Karya.

Doni Koesoema A. (2010). Pendidikan Karakter; Strategi Mendidik Anak di Zaman Global. Jakarta: Grasindo.

Faisal Ismail. (1997). Paradigma Kebudayaan Islam: Studi Kritis dan Refleksi Historis. Yogyakarta: Titian Ilahi Press.

Haidar Putra Daulay. (2007). Pendidikan Islam Dalam Sistem Nasional di Indonesia. Jakarta: Kencana Media.

Hamka Abdul Azis. (2011). Pendidikan Karakter Berpusat Pada Hati. Jakarta: Al-Mawardi Prima.

Howard Kirschenbaum. (2000). 100 Ways to Enchance Values and Morality. Boston: Allyyn and Bacon.

In'am Sulaiman. (2010). Masa Depan Pesantren; Eksistensi Pesantren di Tengah Gelombang Modernisme. Malang: Madani.

Kemendiknas. (2011). Pedoman Pelaksanaan Pendidikan Karakter. Jakarta: Pusat Kurikulum dan Perbukuan Kemendiknas.

Maksudin. (2009). Pendidikan Nilai Komprehensif; Teori dan Praktik. Yogyakarta: UNY Press. 
Masnur Muslich. (2011). Pendidikan Karakter: Menjawab Tantangan Kritis Multidimensional, (Jakarta: Bumi Aksara, 2011), hlm. 133. Jakarta: Bumi Aksara.

Moh. Nizar. (1988). Metode Penelitian. Jakarta: Ghalia Indonesia.

Muhammad Idrus. (2009). Metode Penelian Ilmu Sosial. Jakarta: Erlangga.

Noeng Muhadjir. (2012). Metodologi Penelitian Kualitatif. Yogyakarta: Andi Ofset.

Novan Ardy Wiyani. (2010). Manajemen Pendidikan Karakter, Konsep, dan Implementasinya di Sekolah. Yogyakarta: Pustaka Insan Madani.

Nurul Zuriah. (2011). Pendidikan Moral dan Budi Pekerti Dalam Perspektif Perubahan. Jakarta: Bumi Aksara.

Paul Suparno. (1997). Filsafat Kontruktivisme Dalam Pendidikan. Yogyakarta: Penerbit Kanisius.

Ratna Megawangi. (2010). Pendidikan Karakter; Solusi yang Tepat untuk Membangun Bangsa. Bogor: Indonesia Heritage Foundation.

Sugiyono. (2008). Metode Penelitian Pendidikan (Pendekatan Kuantitatif, Kualitatif, dan RED). Bandung: Alfabeta.

The Random house Dictionary of English Language. (1983). New York: Random House, Inc. 